GadjahMadaInternational Journal of Business

January-April2010, Vol. 12,No. 1,pp.117-133

\title{
INFLATION DYNAMICS IN INDONESIA: EQUILIBRIUM CORRECTION AND FORWARD-LOOKING PHILLIPS CURVE APPROACHES*
}

\author{
Insukindro \\ Professor of Economics, Faculty of Economics and Business, \\ Universitas Gadjah Mada, Yogyakarta, Indonesia \\ Gumilang Aryo Sahadewo \\ Graduate student, Department of Economics, Boston University, U.S.
}

\begin{abstract}
A series of relatively high inflation characterize Indonesian economy, especially during the economic crisis. Economists generally agree that high inflation is one of the major economic problems, and that economic authorities need to cope with such a problem. Therefore, it is essential to understand the behavior of inflation in Indonesia. The aim of this paper is to estimate the inflation dynamics in Indonesia using equilibrium correction and forward-looking Phillips Curve approaches. Previous empirical studies show that the equilibrium correction or backward-looking approach may explain the inflation dynamics in Indonesia. The backward-looking specification does not have to be the proper model even if the fact shows that the specification holds. The major innovation of this paper is the application of a forward-looking Phillips curve model. The empirical results-estimated using the Generalized Method of Moments
\end{abstract}

\footnotetext{
* Earlier draft of this paper was presented in a seminar organized by the Master of Science and Doctorate Programs, FEB UGM, Yogyakarta on March 2, 2010, in the GSICS Development Seminar at Kobe University, Japan on March 12, 2010; and in the $191^{\text {st }}$ IDEC Asia Seminar at Hiroshima University, Japan, March 19, 2010. We would like to thank participants in the seminars for their comments and suggestions.
} 
(GMM)-show that the forward-looking Phillips Curve approach dominates the backward-looking behavior. It indicates that after a credible monetary policy announcement, for instance, the former model predicts that economic agents will change their behavior quickly. Therefore, the policy will affect the economy more rapidly.

Keywords: equilibrium correction; forward-looking; GMM; inflation; Phillips curve

JEL Classification: C22, C51, E31

\section{Introduction}

Inflation phenomenon in Indonesia is unique compared to that in other Asian countries due to the involvement of numerous contributing factors. In addition, the movement of inflation during economic crisis is typical. The collapse of banking sector led to financial breakdown, political turmoil, lengthy spell of drought, tight monetary policy, oil prices hike, and international economic crisis; all contributed to the high inflation in Indonesia. The aforementioned phenomena basically stem from a starting point, which is the behavior of agents in the economy. Study on agent behavior in relation to inflation is essential since agent behavior is directly influenced by the agent's expectations. It is also motivating to observe inflation dynamics in Indonesia given its nature as a developing country. The emblematical imperfection of information and problematic institutions in Indonesia fundamentally influence agent behavior and eventually agents' expectations.
Formorethanhalfa century, Phillips Curve has stimulated numerous academic debates and inquiries among economists. The debates have sparked discussion onkey macroeconomic variables influencing inflation dynamics or on agent behavior toward inflation, i.e., agents' expectations. Neoclassical economists argue that expectations are backward-looking whereas New Classical economists suggest that expectations are rational, thereby forwardlooking (Whelan 2005). Later on, the new breed of macroeconomic theory, New Neoclassical Synthesis (henceforth NNS), integrates rational expectations as one of its basic elements (see for examples Goodfriend and King 1997; Goodfriend 2004, 2008; Zouache 2004; and Giese and Wagner 2007 for further discussion on NNS).

There have been many studies of inflation dynamics in Indonesia (see for examples Ramakrishnan and Vamvakidis 2002; Adrison 2002; Hossain 2005; Anglingkusumo 2005; and Puzon 2009). Ramakrishnan and 
Insukindro\&Sahadewo-InflationDynamicsinIndonesia

Vamvakidis (2002) show that base money and productivity as well as exchange rate and foreign inflation are the key indicators of inflation in Indonesia. Adrison (2002) studies the effects of government expenditures and money supply shocks on Indonesian economy. He notes that money supply shock does not significantly influence output and inflation. Hossain (2005) finds that there exists a long-run causal relationship between money supply growth and inflation.

Anglingkusumo (2005) employs several P-star models, including a simpleMarkov-SwitchingP-star model, to verify that inflation is always a monetary phenomenon in the long run. He finds that excess money supply $\left(\mathrm{M}_{1}\right)$ traces the long-run dynamics of CPI inflation very well. He also notes that changes in inflation are determined by the excess of money shocks and periodic price adjustments to eliminate such shocks in the period of crisis. He concludes that money still acts as the prime mover of inflation even when expectations are stable. Puzon (2009) studies the inflation dynamics in ASEAN-4 countries (i.e., Philippines, Thailand, Malaysia, and Indonesia), andalso finds that the control variables of inflation in the countries in question are different.

Previous empirical studies discussed above have successfully explained the behavior of inflation dynamics in Indonesia. We should note that those studies generally applied the equilibrium correction or the error correction or the backward-looking approaches to their econometric analy- ses. Price and Insukindro (1994) argue that even if such specification holds, it does not necessarily imply that the proper model is backward-looking.

The main purpose of our study is to analyze the nature of expectations in inflation dynamics in Indonesia. We aim to explain the formation of agents' expectations that determine the inflation dynamics and to construct backward- and forward-looking models. We will also employ the equilibrium correction model with shock variable since some previous studies observe the importance of money supply shock to inflation (see Anglingkusumo 2005; Khan and Moessner 2004).

This study yearns to present the insights into inflation dynamics that are consistent with recent development of forward-looking Phillips Curve. There will be different policy implications since backward- and forward-looking hold opposing behaviors. A credible policy will be exercised immediately into agents' decision-making if the forward-looking framework holds. Agents, on the other hand, will wait for data realization before making any decision if backward-looking framework prevails (see also Price and Insukindro 1994). Policy will take more time to have effects if the backward-looking framework holds rather than the forward-looking framework.

The paper is organized in five Sections. Following the introduction, Section 2 reviews related theories and previous researches. Section 3 summarizes the methodology, and Section 4 discusses the empirical results of this 
research. The final Section presents our conclusion.

\section{Review of Related Literature}

Philips Curve (1958) originally estimates a negative relationship between nominal wage inflation and unemployment in the U.K. Since then, it has played an essential role in explaining the inflation dynamics in economy. The ongoing debate on inflation dynamics, mainly in the New-Keynesian Phillips Curve (NKPC) framework, is whether forward-looking behavior has the ability to explain inflation. The model of NKPC shows that inflation is determined by the expectations of future inflation and a driving variable such as real marginal cost, output gap, or unemployment.

Results of various studies offer mixed verification. Galí and Gertler (1999) establish the so-called "hybrid model" in which backward- and forward-looking behaviors are integrated to estimate the NKPC. Real marginal cost is used instead of output gap as the forcing variable of inflation, and inflation is assumed to be the present-value of expected future real marginal cost. They confirm that forward-looking behavior is an important measure of inflation in the U.S. via the hybrid model. The study also shows that the backward-looking behavior is not quantitatively important despite its significance. Galí et al. (2001) observe inflation in Euro countries and prove, albeit not as the main objective of the study, that inflation is influenced by forward- looking behavior. Later on, Tillmann (2005) uses a distinct model to reveal that inflation in U.K. is the realization of expected future real marginal cost; accordingly, inflation is forward-looking.

Several studies disagree that forward-looking specification has the ability to explain inflation. Rudd and Whelan (2001) find that the present value of expected future driving variables, output gap and real marginal cost, could only explain a small portion of actual inflation. A number of studies consider that the test of hybrid model is rather weak compared to thenon-nested backward-looking specification (see also Rudd and Whelan 2003; Bardsen et al. 2005; and Dorich 2009 for more discussion on this issue).

Our study enters the debate by estimating the inflation dynamics with a forward-looking specification, and tests such specification with a backward-looking one to observe which model specification is superior to explain the inflation dynamics in Indonesia. We turn to model specification and testing in the next section.

\section{Model Specification}

Inflation is driven by unemployment in the long run as revealed by the Phillips Curve. In the later development of Phillips Curve, inflation is determined by the deviation of short-run unemployment from its long-run track. As output is associated with unemployment, it has become one of the driving variables in the inflation determination 
(see Williamson 2008: Ch. 17). We shall note that the expected sign of the parameter when using output will be different from that of unemployment. Assuming log linearity, we can write the price equation in period $t$ as follows.

$$
p_{t}=\alpha+\beta x_{t}
$$

where $x$ are the driving variables (a vector of variables influencing price). Equation (1) explains the long-run or equilibrium relationship between price level and its driving variables. However, economic systems are often drifted away from the equilibrium(Thomas 1997: 383). It is generally argued that economic agents will find that the actual $p_{t}$ will diverge from the planned or desired $p_{t}{ }^{*}$. The divergence may be caused by shock variable and subsequent slow adjustment. Therefore, in this case, we also assume that agents attempt to minimize the following quadratic loss function (Domowitz and Elbadawi 1987; and Insukindro 1992).

$$
\begin{aligned}
\mathrm{L}= & \alpha_{1}\left[\hat{\mathrm{p}}_{\mathrm{t}}-\mathrm{p}_{\mathrm{t}}^{*}\right]^{2}+ \\
& \alpha_{2}\left[(1-\mathrm{L})\left(\hat{\mathrm{p}}_{\mathrm{t}}-\mathrm{j} \mathrm{z}_{\mathrm{t}}\right)\right]^{2}
\end{aligned}
$$

where

$$
\mathrm{p}_{\mathrm{t}}=\hat{\mathrm{p}}_{\mathrm{t}}-\mathrm{s}_{\mathrm{t}}
$$

Hence, substitute equation (3) into (2), and we can write (2) as

$$
\begin{aligned}
L= & \alpha_{1}\left[p_{t}-s_{t}-p_{t}^{*}\right]^{2}+ \\
& \alpha_{2}\left[(1-L)\left(\hat{p}_{t}-s_{t}-j z_{t}\right)\right]^{2}
\end{aligned}
$$

where $\hat{p}_{t}$ is short-run planned $p_{t}$ and $p_{t}^{*}$ is desired or long-run $p_{t}$ and $z_{t}$ is a vector of variables influencing $p_{t}{ }^{*}$ and $j$ is a row vector that weights each element of $z_{t}$. Variables $s_{t}$ and $L$ are shock variable and lag operator, respectively. The first component of loss function (4) represents the disequilibrium cost, which is the cost of being away from static equilibrium, whereas the second one is the adjustment cost. The parameters $\alpha_{1}$ and $\alpha_{2}$ are the weights on which the agents place the disequilibrium cost and the adjustment cost, respectively.

We can solve and reparameterize equation (4) to yield the following Equilibrium Correction Model or Error Correction Model (ECM) with shock variable [to derive equation (5), see Insukindro $(1992,1998)]$.

$$
\begin{aligned}
\Delta \mathrm{p}_{\mathrm{t}}= & \gamma_{1} \Delta \mathrm{x}_{\mathrm{t}}-\gamma_{2} \varepsilon_{\mathrm{t}}+\gamma_{3} \Delta \mathrm{s}_{\mathrm{t}}+ \\
& \gamma_{4} \mathrm{~s}_{\mathrm{t}-1} \ldots \ldots \ldots \ldots \ldots \ldots \ldots \ldots \ldots \ldots \ldots \ldots \ldots \ldots \ldots
\end{aligned}
$$

We shall make assumptions before we establish the forward-looking specification. Domowitz and Elbadawi (1987:262) state that in a fully rational world, the behavior of an individual agent is generally assumed to be established in reference to an infinite discounted sum of his or her expected value of the loss function. We assume that forward-looking agents are expected to minimize the following loss function (see Cuthbertson 1988; Price and Insukindro 1994; and KoutsomanoliFilippaki et al. 2008). 
Gadjah Mada InternationalJournal of Business,January-April 2010, Vol. 12,No. 1

$$
\begin{aligned}
\mathrm{L}= & \mathrm{E} \sum_{\mathrm{i}}^{\infty} \mathrm{D}_{\mathrm{t}}\left\{\mathrm{b}_{1}\left[\mathrm{p}_{\mathrm{t}}-\mathrm{p}_{\mathrm{t}}^{*}\right]^{2}+\right. \\
& \left.\mathrm{b}_{2}\left[(1-\mathrm{L}) \mathrm{p}_{\mathrm{t}}\right]^{2}\right\} \ldots \ldots \ldots \ldots \ldots \ldots
\end{aligned}
$$

We use Sargent's method of forward operators as shown in Sargent (1979, Chapter IX) to construct the forward-looking specification below.

$$
\begin{aligned}
p_{t}= & \lambda p_{t-1}+(1-\lambda)(1- \\
& \lambda d) \sum_{s=0}^{\infty}(\lambda D)^{s} E_{t}\left\{p_{t+s}^{*}\right\} \ldots . .(7)
\end{aligned}
$$

Equation (7) has only two parameters, which are the coefficient on the lagged dependent variable, $\lambda$, and the discount factor, D. $E$ denotes the conditional expectation based on all information available at time $t$. The coefficient of $\lambda$ is associated with the speed of adjustment. We must note that the values of the optimal price level or $p^{*}$ are unobservable, thus we will solve this situation in the estimation. We utilize the forecast of preferred methods for the values of $p^{*}$ before we incorporate them into our model. We may write (7) as

$$
\mathrm{p}_{\mathrm{t}}=\lambda \mathrm{p}_{\mathrm{t}-1}+\delta\left(\mathrm{L}^{-1}\right) \mathrm{E}_{\mathrm{t}}\left\{\mathrm{p}_{\mathrm{t}}^{*}\right\}
$$

where $\delta\left(L^{-i}\right)$ is a polynomial in the lead operator.

\section{Econometric Methodology}

\section{Short-Run Dynamics Estimation}

Time series data are stochastic in general, hence time series analysis oblige researchers to observe the nature of the data before moving on to estimate the specification. The foremost step in acquiring necessary information containing the nature of the data is the inference on the data order of integration. We should examine whether the data are integrated of order zero, $I(0)$, or integrated of order one, $I(1)$. We employ the standard Augmented Dickey-Fuller (ADF) and Phillips-Perron (PP) to test the data order of integration.

We may employ several estimation methods, such as autoregressive distributed-lag (ARDL) model, Partial Adjustment Model (PAM), and Shock Absorber Model (SAM). We should note that data are usually stochastic or $I(1)$, hence estimations with the methods above may lead to a spurious regression. Engle and Granger (1987) propose a two-step error correction mechanism (ECM) to estimate data with such nature. The mechanism is extensively applied to test the cointegration of several variables, but we must be certain in the relationships among variables in reference to the theory. We may apply Johansen maxi- 
Insukindro\&Sahadewo - InflationDynamicsinIndonesia

mum likelihood test of cointegration as revealed by Johansen (1988) if we are uncertain about the underlying theory of variables' relationships.

We may also find another phenomenon that has a different order of integration of the estimated variables. We may not use the methods above since the condition is that the variables are integrated in the same order whether it is $I(0)$ or $I(1)$. We may argue that the estimation of $\mathrm{I}(0)$ and $\mathrm{I}(1)$ variables altogether will generate a phony relationship. Pesaran and Shin (1995) find an answer to such a quandary by proposing the ARDL approach to cointegration. The proposed approach is capable of testing the cointegrating relationship between $\mathrm{I}(0)$ and I(1) or even mutually integrated variables.

We shall decide on the class of estimator to be used in the estimation of the specifications. The extensively used OLS method has some disadvantages as it is inept in the estimation of nonlinear parameters as well as non-linear rational expectations model. Hansen and West (2002) reveal that the estimator of Generalized Method of Moments or GMM can solve a model with linear variables but subject to nonlinear restrictions on the parameters. Wooldridge (2001) argues that GMM is proficient in estimating a sophisticated non-linear rational expectation model, and reveals that such estimator takes into account of serial correlation of unknown forms as well as heteroscedasticity. Hansen and West (2002) and Verbeek (2008:161) affirm the argument by noting that GMM does not require a parametric model for conditional heteroscedasticity or any distributional assumption. Our study chooses the best approaches based on the nature of our data as well as our model. We aim to establish a robust model to explain the inflation phenomenon in Indonesia.

\section{Monetary Variable Shock}

Khan and Moessner (2004), and Adrison (2002) and Anglingkusumo (2005) observe that monetary shock is essential in price determination in the U.K. and Indonesia, respectively. Our constructions of equilibrium correction specifications include such shock variable. We integrate short- and long-run shocks in the backward-looking specification since it is assumed that the movement of money supply is persistent in influencing price.

We employ the Box-Jenkins methodology framework to estimate the best ARIMA model of money supply $\left(\mathrm{M}_{2}\right)$ in Indonesia. We use the residuals of the ARIMA model as the proxy for the shock variable. We apply this method in the light of Insukindro (1998) who applied the residuals of $A R(2)$ and the deviations of reserve money from its linier trend as the proxies for shock variable in question.

\section{Forward-Looking Specification}

We are faced with a situation in which the estimation of forward-looking specification (7) has to be made since the future expectation of optimal price level or $p^{*}{ }_{t+s}$ is not directly ob- 
servable. We may employ, for example, Kalman Filter, Hodrick-Prescott Filter, and the fitted values of the cointegrating or equilibrium equation in the ECM estimation to estimate the optimal price level. We choose the fitted values of long-run equation in ECM since it may generate a long-run path. The method undertaken above has been applied by Priceand Insukindro (1994), but not in the context of inflation dynamics in Indonesia and the employment of GMM.

The expected future price level $E\left(p_{t+s}\right)$ will vary from $p_{t+s}$ by a whitenoise random error in the forwardlooking specification. We can state that the variable is correlated to the error term. The orthodox solution of such occurrence is to estimate the model using instrumental variables. The variable is initially regressed on the instrumental variables to get rid of the correlation with the error term. The system will then use the fitted values of the regression to estimate the intended specification.

We may employ several classes of estimators such as two-stage least squares (2SLS), non-linear least squares (NLLS), and GMM to estimate our specifications using instrumental variables. We opt to employ the GMM since our specifications assume non-linear parameters as well as rational expectations in the optimization of the model.

\section{Non-Nested Test}

Wetest our forward-looking specification against the alternate hypothesis of backward-looking specification. Equations (5) and (7) may not be regarded as a nested version of one another, hence they are considered non-nested models. The general test used extensively in testing an alternate hypothesis in non-nested models is Davidson-McKinnon's J-test (Mc Kinnon et al. 1983).

We summarize our econometric methodology to estimate the specifications in the previous section. Initially, we estimate the long-run or cointegrating parameter. Next, we estimate the dynamics using the appropriate method for our backward-looking specification. We then estimate the forward-looking specification and compare it with the backward-looking by employing the Davidson-McKinnon's J-Test.

\section{Empirical Results}

\section{Data}

We use time series data of wholesale price index in Indonesia as our proxy for price level and Gross Domestic Product (GDP) as the driving variable of price level for the period of 1993(I)-2009(III). The data that we use in the estimation are obtained from the International Financial Statistics 
(2010). We use money supply $\left(\mathrm{M}_{2}\right)$ to generate the proxy for monetary shock, which will later be incorporated into our backward-looking model.

Figure 1 shows that for the last decade, the inflation rate in Indonesia has been relatively volatile, except in its economic crisis of 1998. Inflation rate accounted an average of 1.705 percent per quarter or roughly 6.82 percent per annum during the period of 1993(I)1997(III). The inflation rate after the crisis, between 1998 and 2007, was steady at an average of 1.77 percent per quarter.

Indonesia suffered from a high inflation rate, reaching 16 percent in the fourth quarter of 1997 and stretched to a peak of 50.88 percent in the first quarter of 1998. The inflation rate rose to an average of 11.97 percent per quarter during the period of 1998 crisis, between 1997(IV) and 1999(III). The inflation rate reached an average of 2.27 percent between 1999(IV) and 2005(III), which was higher than the average inflation rate before the 1998 economic crisis.

Inflation rate in 2005(IV) reached 10.84 percent since Indonesia was faced with increases in gasoline prices that affected production costs. Oil crisis in the beginning of 2008 also drove the inflation to a rather high average of 5.45 percent per quarter. The high inflation rate has since decreased subsequent to the global slowdown set off by financial crisis. Inflation rate eventually increased in the second and third quarters of 2009 as the economy recovered.

Figure 1. Inflation in Indonesia (in percentage): 1993(I)-2009(III)

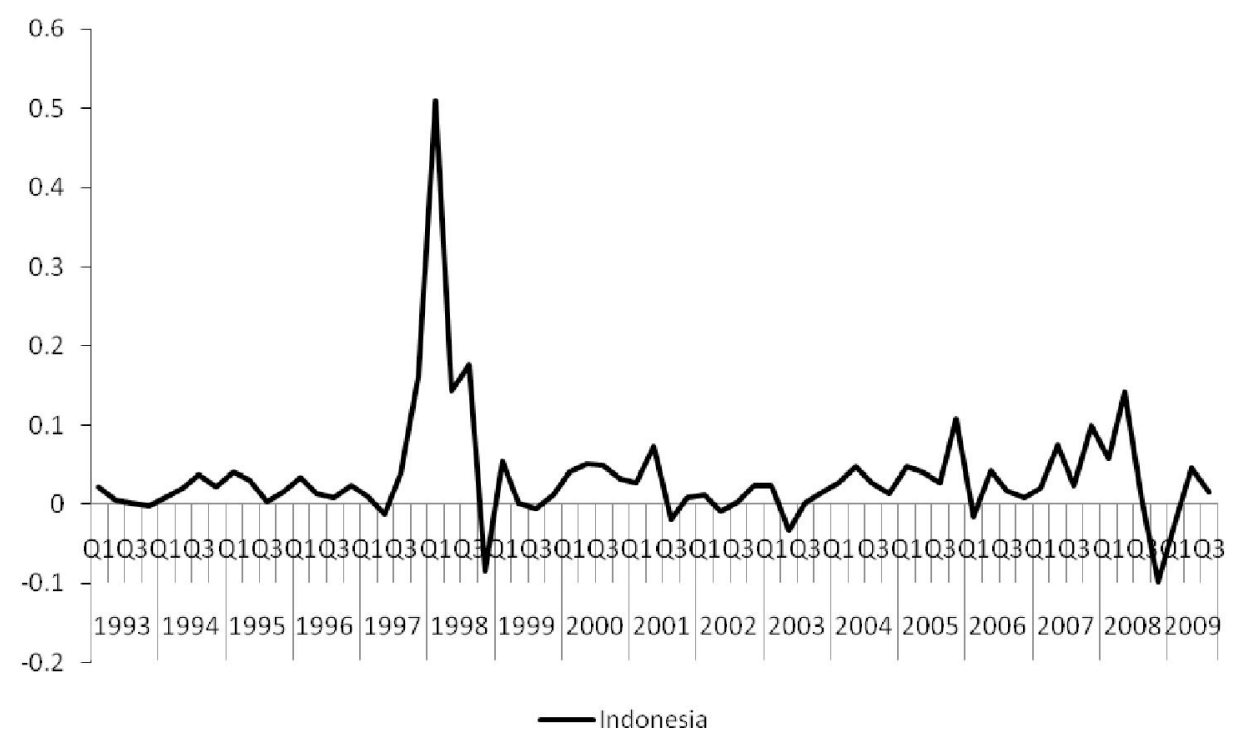

Source: International Financial Statistics (2010) 
Table 1. Order of Integration

\begin{tabular}{|c|c|c|c|c|}
\hline \multirow{3}{*}{ Variables } & \multirow{2}{*}{\multicolumn{2}{|c|}{$\begin{array}{c}\text { Indonesia } \\
\mathbf{I}(0) \\
\end{array}$}} & \multirow{2}{*}{\multicolumn{2}{|c|}{$\begin{array}{c}\text { Indonesia } \\
\text { I(1) } \\
\end{array}$}} \\
\hline & & & & \\
\hline & ADF & PP & ADF & $\mathbf{P P}$ \\
\hline$p_{t}$ & 2.62 & 2.99 & -4.94 & -5.34 \\
\hline$y_{t}$ & 4.60 & 9.37 & -5.39 & -9.35 \\
\hline
\end{tabular}

Notes: $\operatorname{Ln}(\mathrm{P})=\mathrm{p}$ and $\ln (\mathrm{Y})=\mathrm{y}$. Sample, 1993:01 - 2009:03; MacKinnon's critical value for $\mathrm{I}(0)$ test, $95 \%=-1.94$ for $\mathrm{p}$ and $\mathrm{y}$; MacKinnon's critical value for $\mathrm{I}(1)$ test, $95 \%=-3.48$ for $\mathrm{p}$ and $\mathrm{y}$.

Table 2. Inflation in Indonesia: Longrun Estimation, 1993 (I)2009(III)

\begin{tabular}{lc}
\hline & $\mathbf{p}_{\mathbf{t}}$ \\
\cline { 2 - 2 } $\mathrm{c}$ & -6.16 \\
$\mathrm{y}_{\mathrm{t}}$ & 0.80 \\
$\mathrm{ADF}(1)$ & -2.37 \\
$\mathrm{PP}$ & -2.13 \\
\hline
\end{tabular}

Notes: Sample, 1993(I) - 2009(III); MacKinnon's critical value for I(0) test, $95 \%=-1.94$.

\section{Order of Integration}

The first and foremost step in our estimation is the test of variables' order of integration. Our estimation of Indonesian inflation dynamics incorporates wholesale price index $\left(P_{t}\right)$ and GDP $\left(Y_{t}\right)$. We employ ADF and PP for the test, and the results are given in Table 1.
The results of $\mathrm{ADF}$ and $\mathrm{PP}$ tests show that all variables are integrated of order one; in other words, the variables are not stationary in level. A possible approach to estimating our backwardlooking specification given the nature of the data above is the Engle-Granger ECM.

\section{Backward-Looking Specification}

We employ the Engle-Granger ECM to estimate the inflation dynamics in backward-looking framework. The first step of the Engle-Granger ECM is to verify the cointegrating relationship between variables. Table 2 shows the cointegrating relationship between $p$ and $y$.

Readers and analysts might be tempted to interpret the statistics of the long-run regression above, such as $t$-, $F$-, and $\chi^{2}$ statistics. The regression above is in fact spurious since all variables are $I(1)$. All interpretations with 
Insukindro\&Sahadewo - InflationDynamicsinIndonesia

respect to $t-, F$-, and $\chi^{2}$ statistics are consequently subject to biases. Therefore, we are not obliged to report such statistics since it may be misleading.

Table 3. Inflation Dynamics in Indonesia: ECM with Shock Variable

\begin{tabular}{lc}
\hline & $\Delta \mathbf{p}_{\mathbf{t}}$ \\
\cline { 2 - 2 }$\Delta \mathrm{y}_{\mathrm{t}}$ & 0.431 \\
& $(4.917)$ \\
ect $_{\mathrm{t}-1}$ & -0.139 \\
& $(-2.367)$ \\
$\Delta{\text { (shock })_{\mathrm{t}}}$ & 0.548 \\
& $(1.979)$ \\
shock $_{\mathrm{t}-1}$ & 0.330 \\
& $(1.005)$ \\
$\mathrm{R}^{2}$ & 0.398 \\
SE & 0.057 \\
J-stat & 0.15 \\
\hline
\end{tabular}

Notes: Reports of GMM estimation of the parameters and $t$-statistics in parentheses; GMM estimation of Indonesian data uses five lags of price and money supply; Fixed numbers of Newey-West estimate of the covariance are used; J-stat, probability of J-statistics with null hypothesis of overidentification condition satisfied. We also introduce dummy variable (1998:I) in order to investigate the effect of Indonesian economic crisis in $1997 / 1998$ on our model, but the results seem to be spurious and are not in line with our expectations.
The possible interpretation of the regression above is the sign and the magnitude of parameter coefficient. The sign of the coefficient is positive as suggested by the theory, and the magnitude of the coefficient that explains the short-run effect of PDB growth on inflation is below unitary (1) as expected.

Unit root tests on the residuals of the long-run regression above show that we have relatively weak evidence of cointegrating relationship between the variables. However, we may continue to the second step of ECM-EG, which is the equilibrium correction estimation.

The ECM functions as our backward-looking specification which will later be compared with the forwardlooking model. Short- and long-term money supply shocks are also included in our backward-looking specification (5). We exercise GMM to estimate the equilibrium correction specification as discussed before.

Wooldridge (2001), as previously mentioned, suggests that GMM estimation has already taken account of an unknown form of serial correlation as well as heteroscedasticity. Therefore, it is unnecessary to disclose the diagnostic reports of GMM estimation above. There is a note that GMM estimation requires overidentification condition to be fulfilled, and our model has done so. In addition, the $R^{2}$ of the estimation is respectable for the estimation of differences. 
The ECM specification is well defined as shown in Table 3. The parameter of GDP growth has a sensible magnitude and is correctly signed. The error correction term coefficient and $t$-statistic provide evidence of the existence of cointegration, but the magnitude of the coefficient suggests a slow adjustment. There is weak evidence that money supply shock may have an effect on price determination in the short run but not in the long run. It may indicate that the shock is only temporary in influencing inflation in Indonesia.

Our findings in terms of short-run money supply shock basically substantiate previous studies. Anglingkusumo (2005) argues that the influence of excess money on inflation is not immediate and will be characterized by long delays. Adrison (2002) reveals that a change in money supply shock does not influence inflation rate significantly.

\section{Forward-Looking Specification}

The optimal value of price or $p_{t}^{*}$ makes use of the long-run parameter from the cointegrating estimation in Table 2. The lead of the optimal value is employed in the forward-looking specification.

Table 4 shows that the forwardlooking specification in Indonesia is well defined in a simple dynamic equation. The magnitudes of the coefficients are sensible and properly signed. The computed discount factor is also reasonable as predicted in previous
Table 4. Inflation Dynamics in Indonesia: Forward-Looking Specification

\begin{tabular}{lc}
\hline & $\boldsymbol{p}_{\boldsymbol{t}}$ \\
\cline { 2 - 2 }$\lambda$ & 0.026 \\
& $(0.533)$ \\
& 0.811 \\
& $(20.978)$ \\
$D$ & 0.942 \\
& $(4.812)$ \\
Dummy & 0.035 \\
& $(1.992)$ \\
$R^{2}$ & 0.983 \\
SE & 0.072 \\
J-stat & 0.21 \\
\hline
\end{tabular}

Notes: Reports of GMM estimation of the parameters and $t$-statistics in parentheses; GMM estimation of Indonesian data uses five lags of price and money supply; Fixed numbers of Newey-West estimate of the covariance are used; J-stat, probability of J-statistics with null hypothesis of overidentification condition satisfied. The parameter of dummy variable is of sensible magnitude. Dummyis fairlysignificant at the 5 percent level.

studies. The values of $\lambda$ in the specification shows that, as expected, the speed of adjustment is faster than the result obtained in the previous backward-looking estimation. 
Insukindro\&Sahadewo-InflationDynamicsinIndonesia

Forward Versus Error Correction Specification

We focus on the models' predictive performance by observing the bias, variance, and covariance proportion as Pindyckand Rubinfeld(1998:387-388) suggest. We expect the values of bias and variance proportion to be near to zero, and the value of covariance proportion to be near to unity. A high value of bias proportion (exceeding 0.20) verifies a predictive failure of the model since it illustrates a systematic error of the model. It is also suggested that we opt for a model with the lowest mean absolute error as well as mean absolute percentage error.

The predictive performance of the forward-looking specification is better than that of the backward-looking speci- fication as shown in Table 5. The informal analysis suggests that the forward-looking specification in Indonesia outruns the backward-looking one. We must run the formal test afterwards - using the non-nested test - to decide on which model is the best.

The methodology of non-nested test is as follows. Fitted values of each specification are incorporated into the alternative specification. If the parameter of the fitted values is significant, the null hypothesis is rejected against the alternative, and vice versa. We should take notice of the condition that the parameter coefficient should be positive in the interval $[0,1]$, hence a one-sided test is the most suitable (Price and Insukindro 1994). The results are assembled in Table 6.

Table 5. Predictive Performance

\begin{tabular}{|c|c|c|}
\hline Criterion & Backward-looking & Forward-looking \\
\hline Mean Absolute Error & 3.030 & 2.375 \\
\hline Mean Absolute Percentage Error & 3.687 & 3.037 \\
\hline Bias Proportion & 0.063 & 0.035 \\
\hline Variance Proportion & 0.023 & 0.003 \\
\hline Covariance Proportion & 0.914 & 0.962 \\
\hline
\end{tabular}

Table 6. Non-nested Test

\begin{tabular}{|c|c|c|c|c|}
\hline & $\mathbf{H}_{0}$ & $\mathbf{H}_{1}$ & Coefficient & t-statistics \\
\hline \multicolumn{5}{|l|}{ Indonesia } \\
\hline & Forward & Backward & -0.050 & -0.217 \\
\hline & Backward & Forward & 0.012 & 2.323 \\
\hline
\end{tabular}


The non-nested test reveals that the forward-looking specification is not rejected in favor of the backwardlooking specification. Rather, the backward-looking specification is rejected in favor of the forward-looking specification. The results of the test conclude that the forward-looking specification is superior to the backward-looking one.

\section{Conclusion}

Indonesia possesses distinctive inflation behavior given its nature or characteristics as a developing country, such as information imperfection and problematic institutions. Indonesia is also an open economy such that internal as well external shocks may contribute to inflation determination. Thorough knowledge of the factors that influence the inflation behavior in Indonesia is then essential.

Our major contribution in the discussion of inflation dynamics in Indonesia is the construction of equilibrium error with shock variable and the forward-looking specification based on the Phillips Curve and the nature of agent behavior. Our backward- and forward-looking specifications arewell defined according to our expectation as well as general theory. One of our findings, albeit not a pivotal one, is an indication that monetary shock may have a temporary effect on inflation.

Estimation results of the inflation dynamics reveal that agents seem to be forward-looking or rational. Informal comparisons as well as the formal Davidson-McKinnon J-test are performed between backward- and forward-looking specifications. Both comparisons affirm that the forward-looking specification is superior to the backward one. The results of our estimation through non-linear models verify that the Phillips Curve is non-linear.

Agents' responses will be rather delayed since agents wait for available information as well as policy announcements before making any decision in the backward-looking framework. On the other hand, agents have prior expectations in the forward-looking framework. Hence, when they receive credible policies, they will implement their responses in a flash. If the later framework holds, as we believe, changes in credible policies will affect the economy more quickly. Policymakers will have a better prospect for successful policy implementation if they acquire adequate knowledge of the behavior of agents. 
Insukindro\&Sahadewo-InflationDynamicsinIndonesia

\section{References}

Adrison, V. 2002. The effect of money supply and government expenditure shock in Indonesia: Symmetric or asymmetric? Working Paper 02/18. Georgia State University Andrew Young School of Policy Studies

Anglingkusumo, R. 2005. Money-inflation nexus in Indonesia.Discussion Paper 054/4. Tinbergen Institute.

Bardsen, G., O. Eitrheim, E. S. Jansen, and R. Nymoen. 2005. The Econometrics of Macroeconomic Modeling. New York: Oxford University Press, Inc.

Cuthbertson, K. 1988. The demand for M1: A forward looking buffer stock model. Oxford Economic Papers 40: 110-131.

Domowitz, I., and L. Elbadawi. 1987. An error correction approach to moneydemand: The case of Sudan. Journal of Development Economics 26: 257-75.

Dorich, J. 2009. Forward looking versus backward looking behavior in inflation dynamics: A new test. $43^{\text {rd }}$ Conference of Canadian Economics Association, downloaded from http://economics.ca/2009/papers/0241.pdf.

Engle, R. F., and C. W. Granger. 1987. Cointegration and error correction: representation, estimation, and testing. Econometrica 55:251-76.

Gali, J., and M. Gertler. 1999. Inflation dynamics: A structural econometric analysis. Journal Monetary Economics 44: 195-222.

Gali, J., M. Gertler, andD. V. Salido. 2001. European inflation dynamics. European Economic Review45: 1237-1270.

Goodfriend, M. 2004. Monetary policy in the New Neoclassical Synthesis: A primer. Economic Quarterly, Federal Reserve Bank of Richmond(90/3): 21-45.

Goodfriend, M. 2008. The case for price stability with a flexible exchange rate in the New Neoclassical Synthesis. Cato Journal 28: 247-254.

Goodfriend, M., and R. G. King. 1997. The New Neoclassical Synthesis and the role of monetary policy. NBER Macroeconomics Annual: 971-987.

Giese, G., and H. Wagner. 2007. Graphical analysis of the new neoclassical synthesis. Diskussionsbeitrag: 411.

Hansen, B. E., and K. D. West. 2002. Generalized method ofmoments and macroeconomics. Journal of Business and Economic Statistics 20: 460-469.

Hossain, A. 2005. The sources and dynamics of inflation in Indonesia: An ECM model estimation for 1952-2002. Applied Econometrics and International Development 5 (4):93-116.

Insukindro. 1992. Dynamic specification of demand for money: A survey of recent developments. Indonesian Economic Journal 1: 8-23.

Insukindro. 1998. Pendekatan stok penyangga permintaan uang: Tinjauan teoritik dan sebuah studi empirik di Indonesia [The buffer stock approach to the demand for 
Gadjah Mada InternationalJournal of Business, January-April 2010,Vol. 12,No. 1

money: A theoretical review and an empirical study in Indonesia]. Ekonomi dan Keuangan Indonesia 46: 451-471.

International Monetary Fund(IMF). 2010. International Financial Statistics. International Monetary Fund Website, downloaded January 2010 from www.imfstatistics.org/imf/ logon.aspx.

Johansen S. 1988. Statistical analysis of cointegrating vectors. Journal of Economic Dynamic and Control 12:231-54.

Khan, H., and R. Moessner. 2004. Competitiveness, inflation, and monetary policy. Bank of England Working Paper 246.

Koutsomanoli-Filippaki, A., E. Mamatzakis, and S. Christos. 2008. European Banking Integration Under a Quadratic Loss Function. http://efmaefm.org/OEFMAMEETINGS/ EFMA\%20ANNUAL\%20MEETINGS/2008-athens/647.pdf.

McKinnon, J. G., R. Davidson, and H. White. 1983. Tests for model specification in the presence of alternative hypotheses. Journal of Econometrics 21: 53-70.

Pesaran, H. M., and Y. Shin. 1995. Autoregressive distributed lag modeling approach to cointegration analysis. DAE Working Paper Series (9514). Department of Applied Economics University of Cambridge.

Phillips, A. W. 1958. The relation between unemployment and the rate of change of money wage rates in the United Kingdom 1861-1957. Economica 25: 283-299.

Pindyck, R., and D. Rubinfeld. 1998. Econometrics Model and Economic Forecasts (4 $4^{\text {th }}$ ed.). Singapore:McGraw-Hill, Inc.

Price, S., and Insukindro. 1994. The demand for Indonesian narrow money: Long run equilibrium, error correction, and forward looking behavior. The Journal of International Trade and Economic Development 3 (2): 147-63.

Puzon, K. A. 2009. The inflation dynamics of ASEAN-4: A case study of thePhillips curve relationship. Journal of American Science 5 (1): 55-57.

Ramakrishnan, U., and A. Vamvakidis. 2002. Forecasting inflation in Indonesia. IMF Working Paper (WP/02/111).

Rudd, J., and K. Whelan. 2001. New test of the New-Keynesian Philips curve. Finance and Economics Discussion Series (52). Board of Governors of the Federal Reserve System.

Rudd, J., and K. Whelan. 2003. Can new rational expectations sticky-price models explain inflation dynamics. Finance and Economics Discussion Series. Board of Governors of the Federal Reserve System.

Sargent, T. J. 1979. Macroeconomic Theory. Academic Press.

Thomas, R. L. 1997. Modern Econometrics: An Introduction. Addison Wesley.

Tillmann, P. 2005. Does the forward looking Philips curve explain the UK Inflation? Manuscript. Institute of International Economics, University of Bonn.

Verbeek, M. 2008. A Guide to Modern Econometrics ( $3^{\text {rd }}$ ed.). John Wiley \& Sons, Ltd.

Whelan, K. 2005. Topic 7: The New-Keynesian Philips curve. EC4010 Lecture Notes. 
Insukindro\&Sahadewo-InflationDynamicsinIndonesia

Downloaded January 2009 from http://tcd.ie/Economics/staff/whelanka/topic7.pdf.

Williamson, S. D. 2008. Macroeconomics. Pearson Education, Inc.

Wooldridge, J. M. 2001. Applications of generalized method of moments estimation. Journal of Economic Perspectives 15: 87-100.

Zouache, A. 2004. Towards a 'New Neoclassical Synthesis'? An analysis of the methodological convergence between New Keynesian Economics and Real Business Cycle theory. History of Economic Ideas 12: 95-117. 